\title{
Effects of Oral Alprazolam and Oral Tramadol on Anxiety and Analgesia in Patients Undergoing Breast Cancer Surgery
}

\section{Meme Kanseri Cerrahisi Geçirecek Hastalarda Oral Alprazolam ve Oral Tramadol Premedikasyonun Anksiyete ve Analjezi Üzerine Etkileri}

(1) Burak AYAN, iD Güniz MEYANCI KÖKSAL

İstanbul University-Cerrahpaşa Cerrahpaşa Faculty of Medicine, Department of Anesthesiology and Reanimation, İstanbul, Turkey

\section{ABSTRACT}

Objective: The aim of this study is to determine postoperative pain and anxiety condition of patients undergoing elective breast cancer surgery who recieved preoperative combination of Tramadol and Alprazolam.

Methods: One hundred and twenty American Society of Anesthesiologists I-III patients undergoing elective breast surgery were enrolled clinically, randomized, prospectively in the study. Patients separated into Group 1 (Alprazolam $1 \mathrm{mg}$ PO + Tramadol $100 \mathrm{mg}$ PO), Group 2 (Alprazolam $1 \mathrm{mg}$ PO + Tramadol $50 \mathrm{mg}$ PO) and Group 3 (conventional premedication-control group). Alprazolam was given to the patients before the night of the operation. Tramadol was given to the patients before $60 \mathrm{~min}$ before the operation. All patients received standard general anesthesia. After extubation, st minute visual analogue scale (VAS) and richmond agitation sedation scale (RASS) values were recorded. In the recovery room, VAS and RASS values were recorded in $20^{\text {th }}$ and $40^{\text {th }}$ minutes and again in $24^{\text {st }}$ hour. For statistical analysis of data, one-way Anova Test, Tukey HSD Test, Tamhane's T2 test were used.

Results: In the postoperative period, levels of agitation caused by anxiety were lower in the patients who received preoperative Alprazolam (Group 1-2) than the patients who did not receive Alprazolam (Group 3) ( $\mathrm{p}=0.007)$. RASS levels were significantly lower in the patients who received preoperative $100 \mathrm{mg}$ Tramadol and $1 \mathrm{mg}$ Alprazolam than the other groups. VAS levels were decreased in time in each group, but there was no difference in VAS levels between groups.

\section{ÖZ}

Amaç: Çalışmada amacımız, elektif meme kanseri cerrahisi uygulanacak kadınlarda preoperatif dönemde verilen tramadolalprazolam kombinasyonunun postoperatif dönemde ağrı ve anksiyete üzerine etkinliğini araştırmaktır.

Yöntem: Çalışmaya elektif meme kanseri cerrahisi uygulanacak 120 hasta klinik, randomize ve prospektif olarak dahil edildi. Hastalar Amerikan Anesteziyoloji Derneği (ASA) sınıflandırmasına göre sınıf 1-3 arasındaydı. Hastalar Grup 1 (Alprazolam $1 \mathrm{mg}$ oral + Tramadol $100 \mathrm{mg}$ oral), Grup 2 (Alprazolam $1 \mathrm{mg}$ oral + Tramadol $50 \mathrm{mg}$ oral), Grup 3 (konvansiyonel premedikasyon-kontrol grubu) olarak 3 gruba ayrıldı. Hastalara operasyondan 1 gece önce alprazolam verildi, operasyondan 60 dakika önce tramadol verildi. Tüm hastalarda standart genel anestezi uygulandı. Ekstübasyon sonrası 1. dakikada vizüel analog skala (VAS) ve richmond ajitasyon sedasyon skalası (RASS) verileri kaydedildi. Postoperatif derlenme odasına alınan hastaların 20. 40. dakika ve 24. saatte VAS ve RASS ölçümleri yinelendi. İstatistiksel analiz için One-Way Anova Test, Tukey HSD Test veTamhane's T2 Test kullanıldı.

Bulgular: Preoperatif alprazolam verilen hastaların (Grup 1-2), Alprazolam verilmeyen hastalara (Grup 3) oranla postoperatif dönemde anksiyete ilişkili ajitasyon daha az yaşadığı saptandı $(\mathrm{p}=0,007)$. Preoperatif $1 \mathrm{mg}$ alprazolam ve $100 \mathrm{mg}$ tramadol verilen gruptaki hastaların RASS değerlerinin diğer gruplardan anlamlı oranda düşük olduğu görüldü. Grup içi VAS değelerinin zaman içinde düştüğü, ancak gruplar arası VAS değerinde farklılık olmadığı görüldü.
Address for Correspondence: Burak AYAN, İstanbul University-Cerrahpaşa Cerrahpaşa Faculty of Medicine, Department of Anesthesiology and Reanimation, istanbul, Turkey E-mail: drburakayan@yahoo.com ORCID ID: orcid.org/0000-0003-2027-8125
Received: 09.04.2020

Accepted: 04.08.2020

Cite this article as: Ayan B, Meyancı Köksal G. Effects of Oral Alprazolam and Oral Tramadol on Anxiety and Analgesia in Patients Undergoing Breast Cancer Surgery. Bezmialem Science 2021;9(4):407-14. 
Conclusion: We found that the preoperative combination of oral administered $100 \mathrm{mg}$ Tramadol and $1 \mathrm{mg}$ Alprazolam resulted in decreased anxiety in the postoperative period in patients undergoing elective breast cancer surgery.

Keywords: Postoperative analgesia, preemtive analgesia, breast cancer, anxiety
Sonuç: Elektif meme cerrahisi uygulanan hastalarda preoperatif oral olarak verilen $1 \mathrm{mg}$ Alprazolam ve $100 \mathrm{mg}$ Tramadol kombinasyonunun, postoperatif dönemde anksiyeteyi azalttığını saptadik.

Anahtar Sözcükler: Postoperatif analjezi, preemptif analjezi, meme kanseri, anksiyete

\section{Introduction}

Breast cancers have emotional and psychological implications for the woman beyond the size of the affected tissue or organ (1). While almost half of patients with cancer experience psychiatric disorders, more than one third of female patients with breast cancer experience psychopathological disorders and anxiety during the disease process (2). Anxiety has many negative effects on the organism, one of which is pain (3) .

In recent years, research on controlling postoperative pain starting from the preoperative period has brought the concept of "preemptive analgesia" to the agenda. The aim of preemptive administration of drugs is to prevent the central sensitization process and to achieve a better analgesia quality after surgery (47).

Tramadol is a commonly used synthetic opioid derivative analgesic agent. Analgesic efficacy has been demonstrated in many studies (8-10). It is also frequently and effectively used in preemptive analgesia.

Alprazolam is a short-acting benzodiazepine commonly used in the treatment of anxiety disorders. Various studies have mentioned the analgesic properties of alprazolam and its use in preemptive analgesia $(11,12)$. Studies showing the postoperative efficacy of opioid and benzodiazepine combinations in breast surgeries are limited.

Unlike the postoperative pain that occurs after breast surgeries performed for other reasons, the postoperative pain experienced by women undergoing breast cancer surgery deteriorates their quality of life more, and the anxiety they experience during this period also has an effect on this pain. In our study, we aimed to reveal the effectiveness of tramadol and alprazolam combination in the preoperative period on pain and anxiety in the postoperative period in female patients who underwent surgery with the diagnosis of breast cancer.

\section{Methods}

The study was conducted with 120 ASA I-III class women in the 20-80 age group who underwent elective breast surgery between 2012 and 2014 in İstanbul University-Cerrahpaşa, Cerrahpaşa Medical Faculty Monobloc Operating Room after obtaining the approval of the Ethics Committee of İstanbul UniversityCerrahpaşa Cerrahpaşa Faculty of Medicine. It was conducted clinically, randomized and prospectively. Before the patients participated in the study, the study was explained to the patients in detail and their written consent was obtained. The study was prepared in accordance with the principles of the Declaration of Helsinki.

A person who was unaware of the study divided the patients into groups by drawing lots. The patients were divided into groups and randomization was achieved in this way.

Patients with a history of drug allergy, decompensated respiratory and circulatory insufficiency, psychiatric disorders, and those requiring follow-up in the postoperative intensive care unit were not included in the study.

The patients were randomly divided into 3 groups:

Group 1: Alprazolam $1 \mathrm{mg}$ orally + Tramadol $100 \mathrm{mg}$ orally were given.

Group 2: Alprazolam $1 \mathrm{mg}$ orally + Tramadol $50 \mathrm{mg}$ orally were given.

Group 3: Midazolam $0.03 \mathrm{mg} / \mathrm{kg}$ was administered intravenously (conventional premedication-control group).

One mg tablet of alprazolam (Xanax $1 \mathrm{mg}$ tablet, Pzifer Inc., New York, USA) was given orally to the premedicated patient groups (Group 1 and Group 2) in the surgical ward the night before the scheduled day of surgery. The group that would receive conventional premedication was not given any medication the night before. Patients were taken to the preoperative preparation room 60 minutes before the operation, intravenous access was established with a 20G cannula for all patients, $50 \mathrm{mg} / 100$ mg tramadol (Contramal $50 \mathrm{mg}$ tablet-Contramal Retard $100 \mathrm{mg}$, Abdi İbrahim, İstanbul, Turkey) was administered to the premedicated groups 60 minutes before the surgery in the recovery unit. The tablet was given orally with $5 \mathrm{~mL}$ of water. Conventional premedication was applied to Group 3 (Demizolam $5 \mathrm{mg}$ ampoule, Dem İlaç, Istanbul, Turkey). Then the patients were taken to the operating room. Standard monitoring was done. After the operation, the visual analogue scale (VAS) and richmond agitation sedation scale (RASS) values were recorded at the $1^{\text {st }}$ minute following extubation. After the patients were taken to the postoperative care room, standard monitoring was applied, oxygen was administered at $4 \mathrm{~L} / \mathrm{min}$ with a simple face mask, and VAS and RASS values were recorded at the $20^{\text {th }}$ and $40^{\text {th }}$ minutes. After the $40^{\text {th }}$ minute, the patients were transferred to the service in accordance with the criteria for leaving the postoperative care room (aldrete score $>9$ ). VAS and RASS values 
were recorded again at the postoperative $24^{\text {th }}$ hour and additional analgesic requirement, nausea and vomiting were questioned.

At the end of the study, preoperative, intraoperative and postoperative recorded VAS and RASS values of all three groups were statistically compared.

\section{Statistical Analysis}

While evaluating the study data, in addition to descriptive statistical methods (mean, standard deviation, median, frequency, ratio, minimum, maximum) in comparison of quantitative data, "One-way Anova Test" in the comparison of groups of three or more with normal distribution and "Tukey HSD" test and "Tamhane's T2" test were used in the determination of the group causing the difference. Kruskal-Wallis test was used in the comparison of groups of three or more that did not show normal distribution, and the "Mann-Whitney U" test was used to determine the group that caused the difference. The Friedman test was used for in-group comparisons of parameters that did not show normal distribution, and the "Wilcoxon Signed Ranks" test was used to evaluate binary comparisons. "Pearson chi-square test" was used in the comparison of qualitative data. Significance was evaluated at $\mathrm{p}<0.01$ and $\mathrm{p}<0.05$ levels.

\section{Results}

\section{Demographic Features}

There was no significant difference between the groups in terms of demographic findings of the patients. Demographic data of the patients are given in Table 1.

\section{VAS Scores}

No statistically significant difference was observed between the groups in terms of VAS scores at the $1^{\text {st }}, 20^{\text {th }}, 40^{\text {th }}$ minutes and $24^{\text {th }}$ hour (Table 2) (Figure 1).

The change (decreases) observed at the $20^{\text {th }}$ minute scores compared to the $1^{\text {st }}$ minute VAS scores showed a statistically significant difference between the groups $(\mathrm{p}=0.032)$. The changes observed at the $40^{\text {th }}$ minute and $24^{\text {th }}$ hour scores compared to the $1^{\text {st }}$ minute VAS scores did not show a statistically significant difference between the groups. The changes observed at the $40^{\text {th }}$ minute and $24^{\text {th }}$ hour scores compared to the $20^{\text {th }}$ minute VAS scores were not statistically significant between the groups (Table 2 ). The changes (decreases) observed in the $24^{\text {th }}$ hour scores compared to the $40^{\text {th }}$ minute VAS scores showed a statistically significant difference between the groups $(\mathrm{p}=0.018)$.

\section{RASS Scores}

Significant differences were observed in the distribution of RASS scores between the groups (Figure 2). A statistically significant difference was observed between the groups in terms of 1 st minute RASS scores ( $\mathrm{p}=0.036)$ (Table 3 ). According to the binary comparisons made to determine the group that created the difference; it was observed that the 1st minute RASS scores of Group 1 patients were statistically significantly lower than the scores of both Group 2 patients and Group 3 patients ( $\mathrm{p}=0.041$

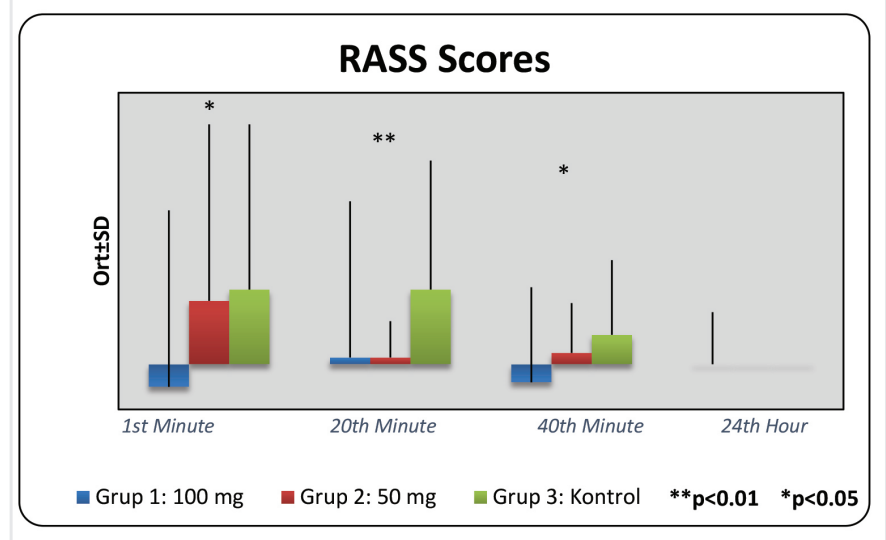

Figure 1. Distribution of VAS scores by groups

VAS: Visual analogue scale

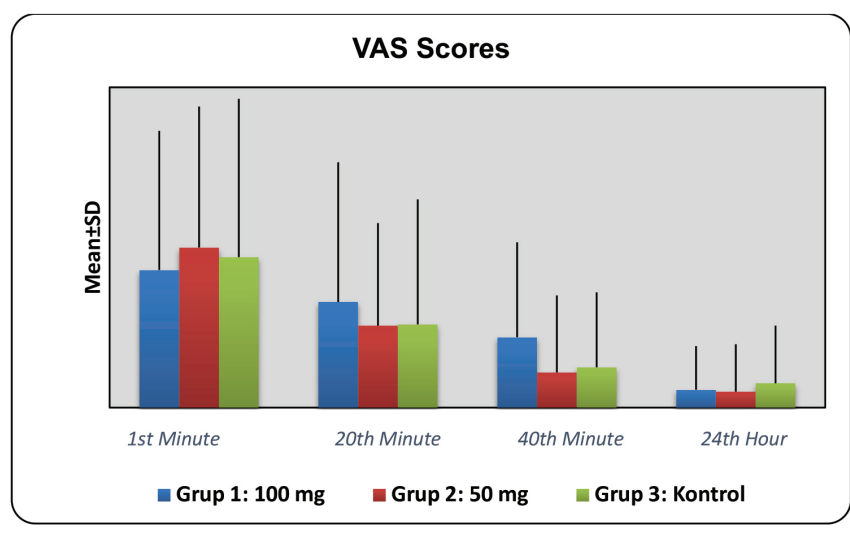

Figure 2. Distribution of RASS scores by groups

RASS: Richmond agitation sedation scale

Table 1. Demographic data of groups

\begin{tabular}{|c|c|c|c|c|c|}
\hline \multicolumn{2}{|l|}{ n (\%) } & $\begin{array}{l}\text { Group } 1 \\
\text { n (\%) }\end{array}$ & $\begin{array}{l}\text { Group } 2 \\
\text { n (\%) }\end{array}$ & Group 3 & $p$ \\
\hline \multirow[t]{2}{*}{ ASA } & $\begin{array}{l}1 \\
2\end{array}$ & $\begin{array}{l}25(62.5) \\
15(37.5)\end{array}$ & $\begin{array}{l}25(62.5) \\
15(37.5)\end{array}$ & $\begin{array}{l}27(67.5) \\
13(32.5)\end{array}$ & ${ }^{\mathrm{a}} 0.865$ \\
\hline & & Mean \pm SD & Mean \pm SD & Mean \pm SD & \\
\hline Age & & $48.35 \pm 12.13$ & $44.75 \pm 9.97$ & $45.85 \pm 9.38$ & b0.299 \\
\hline
\end{tabular}


and $\mathrm{p}=0.017$, respectively). No statistically significant difference was observed between Group 2 patients and Group 3 patients (Table 3a).

A statistically significant difference was observed between the groups in terms of $20^{\text {th }}$ minute RASS scores $(\mathrm{p}=0.007)$ (Table $3)$. According to the binary comparisons made to determine the group that created the difference; it was observed that the $20^{\text {th }}$ minute RASS scores of Group 3 patients were statistically significantly higher than the scores of both Group 1 patients and Group 2 patients ( $\mathrm{p}=0.019$ and $\mathrm{p}=0.002$, respectively). No statistically significant difference was observed between Group 1 patients and Group 2 patients (Table 3a).

A statistically significant difference was observed between the groups in terms of 40th minute RASS scores $(\mathrm{p}=0.007)$ (Table 8). According to the binary comparisons made to determine the group that created the difference; it was observed that the 40th minute RASS scores of Group 1 patients were statistically significantly lower than the scores of Group 3 patients $(\mathrm{p}=0.020$ and $p<0.05$, respectively). No statistically significant difference was observed between the other groups (Table 3).

It was observed that the changes in the measurements made at the $1^{\text {st }}$ minute, $20^{\text {th }}$ minute, $40^{\text {th }}$ minute and $24^{\text {th }}$ hour in Group 1 patients were not statistically significant (Table 3 ).

In Group 2 patients, it was observed that the change between the measurements made at the $1^{\text {st }}$ minute, $20^{\text {th }}$ minute, $40^{\text {th }}$ minute and $24^{\text {th }}$ hour was statistically significant $(\mathrm{p}=0.041)$. It was observed that the change (decrease) in the RASS scores of the patients in this group at the $20^{\text {th }}$ minute and $24^{\text {th }}$ hour compared to the $1^{\text {st }}$ minute RASS scores were statistically significant $(\mathrm{p}=0.041$ and $\mathrm{p}=0.033$, respectively). It was observed that the changes observed at the $40^{\text {th }}$ minute compared to the $1^{\text {st }}$ minute RASS scores were not statistically significant. It was observed that the changes in the direction of decrease observed at the $40^{\text {th }}$ minute and $24^{\text {th }}$ hour compared to the $20^{\text {th }}$ minute RASS scores were not statistically significant. It was observed that the changes in the direction of decrease observed at the $24^{\text {th }}$ hour compared to the $40^{\text {th }}$ minute RASS scores were not statistically significant (Table 3).

In Group 3 patients, it was observed that the change between the measurements made at the $1^{\text {st }}$ minute, $20^{\text {th }}$ minute, $40^{\text {th }}$ minute and $24^{\text {th }}$ hour was statistically significant $(\mathrm{p}=0.001)$. It was observed that the changes in the direction of decrease observed at the $20^{\text {th }}$ and $40^{\text {th }}$ minutes compared to the $1^{\text {st }}$ minute RASS scores in this group were not statistically significant. It was observed that the change in the direction of decrease observed in the $24^{\text {th }}$ hour RASS scores compared to the 1 st minute RASS scores was statistically significant $(\mathrm{p}=0.009)$. Compared to the $20^{\text {th }}$ minute RASS scores, the changes in the direction of decrease observed at the $40^{\text {th }}$ minute and $24^{\text {th }}$ hour were statistically significant ( $\mathrm{p}=0.005$ and $\mathrm{p}=0.002$, respectively). It was observed that the change in the direction of decrease observed at the $24^{\text {th }}$ hour compared to the $40^{\text {th }}$ minute RASS scores was statistically significant $(\mathrm{p}=0.025)$ (Table 3).

Table 2. Evaluations according to VAS scores

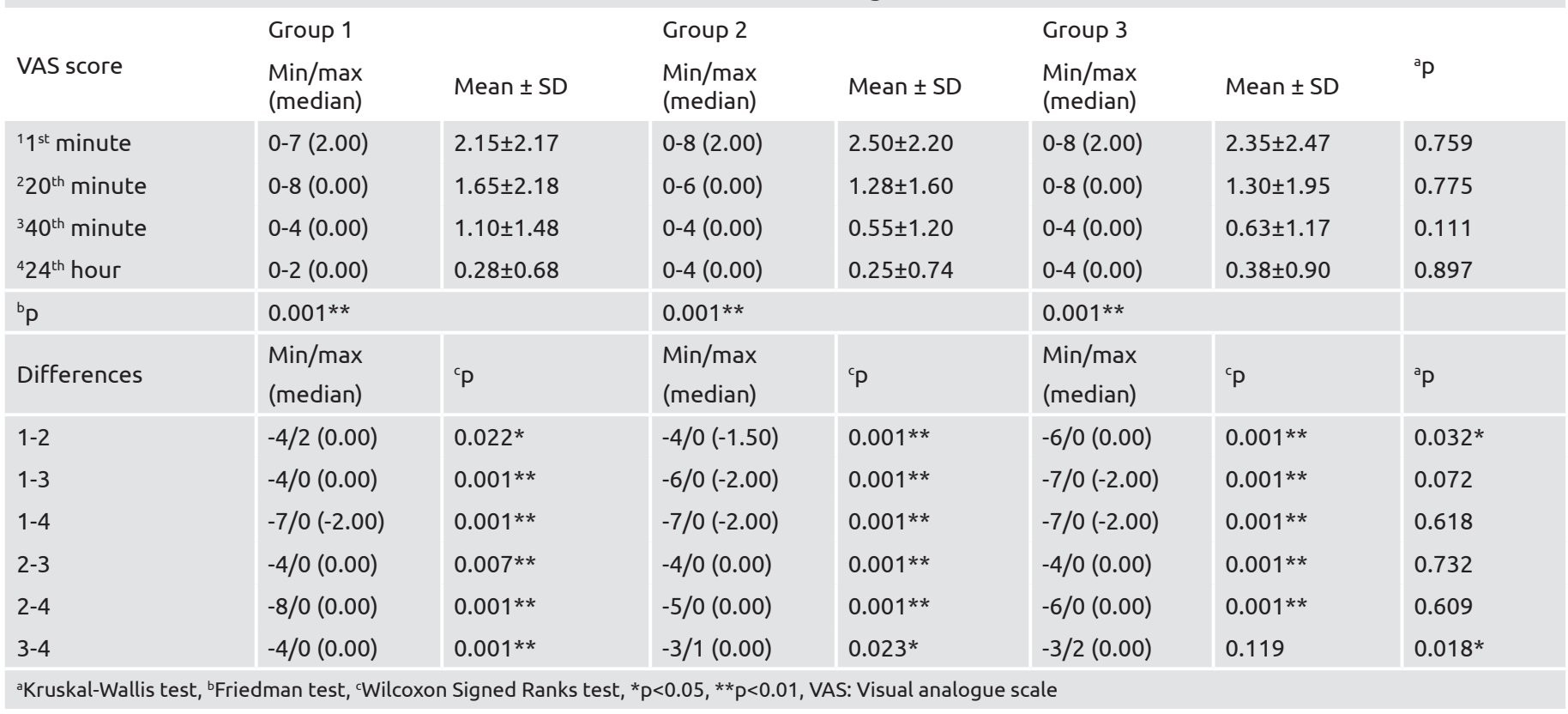

Table 2a. Binary comparisons (post-hoc evaluations)

\begin{tabular}{|c|c|c|c|}
\hline VAS score & Group 1-2 & Group 1-3 & Group 2-3 \\
\hline Difference 1-2 & $0.010^{*}$ & 0.096 & 0.339 \\
\hline Difference 3-4 & $0.019 *$ & $0.017 *$ & 0.845 \\
\hline
\end{tabular}

Mann-Whitney U test, * $p<0.05$, VAS: Visual analogue scale 
Table 3. Evaluations according to RASS scores

\begin{tabular}{|c|c|c|c|c|c|c|c|}
\hline \multirow[b]{2}{*}{ RASS score } & \multicolumn{2}{|l|}{ Group 1} & \multicolumn{2}{|l|}{ Group 2} & \multicolumn{3}{|l|}{ Group 3} \\
\hline & $\begin{array}{l}\text { Min/max } \\
\text { (median) }\end{array}$ & Mean \pm SD & $\begin{array}{l}\text { Min/max } \\
\text { (median) }\end{array}$ & Mean \pm SD & $\begin{array}{l}\text { Min/max } \\
\text { (median) }\end{array}$ & Mean \pm SD & ${ }^{\mathrm{a} p}$ \\
\hline${ }^{1} 1^{\text {st }}$ minute & $-2 / 2(0.00)$ & $-0.10 \pm 0.78$ & $-1 / 2(0.00)$ & $0.28 \pm 0.78$ & $-1 / 2(0.00)$ & $0.33 \pm 0.73$ & $0.036^{*}$ \\
\hline${ }^{2} 20^{\text {th }}$ minute & $-1 / 1(0.00)$ & $0.03 \pm 0.69$ & $0 / 1(0.00)$ & $0.03 \pm 0.16$ & $0 / 2(0.00)$ & $0.33 \pm 0.57$ & $0.007 * *$ \\
\hline${ }^{3} 40^{\text {th }}$ minute & $-2 / 1(0.00)$ & $-0.08 \pm 0.42$ & $0 / 1(0.00)$ & $0.05 \pm 0.22$ & $0 / 1(0.00)$ & $0.13 \pm 0.33$ & $0.035^{*}$ \\
\hline Differences & $\begin{array}{l}\text { Min/max } \\
\text { (median) }\end{array}$ & ${ }^{c} p$ & $\begin{array}{l}\text { Min/max } \\
\text { (median) }\end{array}$ & ${ }^{c} p$ & $\begin{array}{l}\text { Min/max } \\
\text { (median) }\end{array}$ & ${ }^{c} p$ & ${ }^{a} p$ \\
\hline $1-2$ & $-3 / 1(0.00)$ & 0.134 & $-2 / 1(0.00)$ & $0.041^{*}$ & $-2 / 1(0.00)$ & 1.000 & $0.024 *$ \\
\hline $1-3$ & $-2 / 2(0.00)$ & 0.830 & $-2 / 1(0.00)$ & 0.090 & $-2 / 2(0.00)$ & 0.059 & 0.314 \\
\hline $3-4$ & $0 / 1(0,00)$ & 0,083 & $-1 / 0(0,00)$ & 0,157 & $-1 / 1(0,00)$ & $0,025^{*}$ & $0,007 * *$ \\
\hline
\end{tabular}

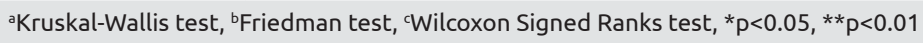

\section{Table 3a. Binary comparisons (post-hoc evaluations)}

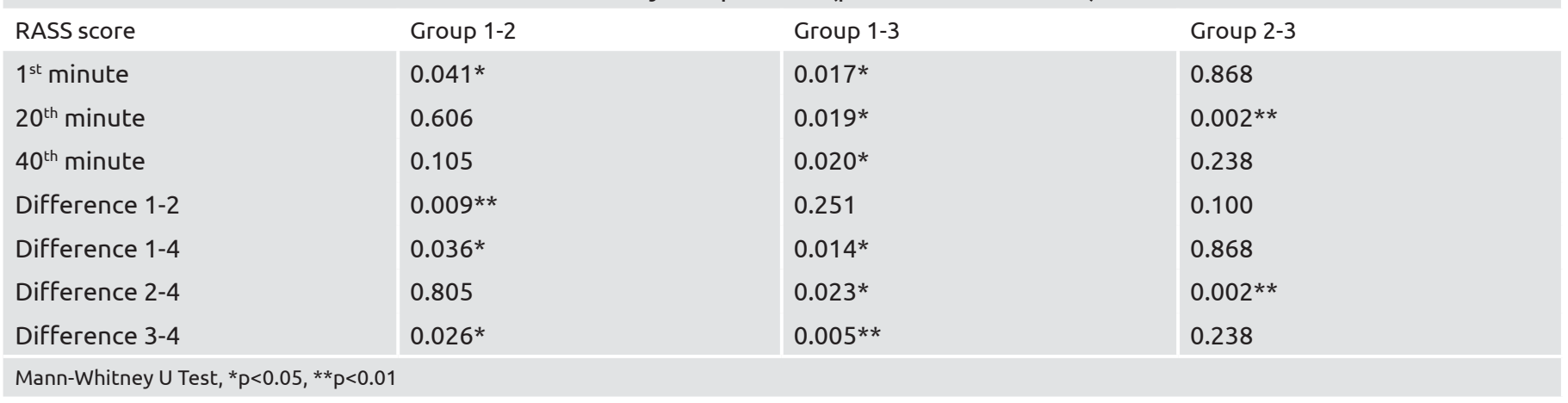

\section{Discussion}

In our study, we aimed to prepare the patients both physically and mentally for the surgery by minimizing the agitation and anxiety experienced by the patients 60 minutes before the operation, and to prevent the feeling of pain caused by agitation and anxiety in the postoperative period. The drugs we chose for this purpose were Alprazolam from the benzodiazepine group, which could be easily administered in hospital wards, and Tramadol, an opioid derivative.

It is known that peroral administration of $1 \mathrm{mg}$ of Alprazolam 1 hour before induction of anesthesia reduces anxiety and agitation without significant side effects ${ }^{13}$. Tramadol, on the other hand, has been used frequently in both postoperative and preemptive analgesia in recent years. In many studies, anxiety and agitation measurements were performed during the preoperative visit (1417). Vickers et al. (18) used anxiety measurement to determine the timing of the preoperative visit in a study they conducted. They measured the patients' anxiety one week before, one day before, and just before the operation, and reported that they could not find a significant difference between these measurements. Lichtor et al. (19) conducted a study to determine whether the anxiety level measured in the afternoon of the day before the operation reflected the anxiety level just before the operation. They reported that there was $70 \%$ correlation between the anxiety levels measured in both periods. Badner et al. (14) also reported that they showed a 73\% correlation between the anxiety levels measured in the afternoon before the operation and just before the operation.

Detection of lower analgesic needs and pain scores during the periods when the clinical active period of antinociceptive therapy was over in patients who underwent preemptive treatment was considered as evidence of preemptive analgesia (20). Wang et al. (21) showed that the pain scores in the first 24 hours after the operation in patients who were given $100 \mathrm{mg}$ of Tramadol before the operation were significantly lower than the group that did not receive Tramadol in their study performed in patients who would undergo total abdominal hysterectomy. In our study, we found that pain scores were lower in the early postoperative period ( $1^{\text {st }}$ minute) in the patient group given 100 
mg Tramadol, similar to this study. But these values were not statistically and clinically significant. Comparing the preemptive efficacy of Tramadol, Pozos-Guillen et al. (22) administered oral Tramadol 1 hour before mandibular third molar tooth extraction to a group, administered oral Tramadol after the procedure in another group and administered saline in control group. It was found that the efficacy of Tramadol given preemptively was $85 \%$. Olmez et al. (23), compared $8 \mathrm{mg}$ Lornoxicam, $100 \mathrm{mg}$ Tramadol and saline infusion in 62 patients who underwent transrectal prostate biopsy. The drugs were administered half an hour before the operation. Tramadol was found to be more effective in the VAS comparison made after the operation. In the literature research of Møiniche et al. (24), 9 studies using opioids as preemptive analgesics were evaluated. In 7 of these studies, no postoperative difference was found between the treatment group and the control group in patients given preoperative opioids. In our study, similar to these studies, we did not find a statistically significant difference in terms of postoperative VAS values in Group 1 and Group 2 patients who received preoperative Tramadol compared to Group 3 patients who did not receive preoperative Tramadol. However, in our study, VAS changes were found to be statistically significant in all groups. We observed a significant decrease in VAS values beginning from the $1^{\text {st }}$ minute to the $24^{\text {th }}$ hour postoperatively in Group 1 and 2 patients. Based on this, we think that Tramadol given preemptively will be effective on postoperative analgesia, although we cannot find a statistical difference. Bösenberg and Ratcliffe (25) found a decrease in pain in the first 2 hours postoperatively when Tramadol was given with a dose of $1-2 \mu \mathrm{g} \mathrm{kg}-1$ before surgery in patients undergoing inguinal surgery. They did not detect a significant difference in pain scores in the first 30-60 minutes. On the other hand, although there was no difference between the treatment and the control group in terms of VAS scores at the end of the postoperative $1^{\text {st }}$ hour, the total analgesic requirement was less. In our study, similar to this study, we did not find a statistically significant difference between the groups in terms of pain scores. However, VAS values were below 4 beginning from the first minute in all our study groups. This might be due to the Remifentanil we administered intraoperatively. In addition, we thought that the limitation of the patients we included in the groups may have caused this. However, such a result may have arisen because VAS is a subjective assessment. Therefore, we think that clinical, prospective, randomized studies with larger patient groups should be conducted.

It has been reported that high preoperative anxiety and agitation in adult patients increase postoperative pain and cause a significant increase in the need for analgesic and sedative drugs. Pasnau et al. (26) found in their studies that the level of postoperative anxiety and agitation was associated with the level of preoperative anxiety. The rate of medical complications is also higher in patients with high postoperative anxiety (27). In addition, inadequate pain management may increase agitation. In our study, similar to these studies, we found higher agitation scores in the patient group who did not receive Alprazolam and Tramadol preoperatively. De Witte et al. (28) administered oral Alprazolam preoperatively to 45 female patients who were going to undergo laparoscopic gynecological surgery and they evaluated the anxiety, sedation level and VAS score postoperatively. As a result of the study, it was found that the VAS score and sedation and anxiety level of the Alprazolam group were significantly lower than the placebo group. In our study, similar to this study, the RASS value measurements made beginning from the $1^{\text {st }}$ minute to the $24^{\text {th }}$ hour postoperatively in the patients who were given Alprazolam $+100 \mathrm{mg}$ Tramadol in the preoperative period were statistically significantly lower than the decrease in the RASS values of the patients who were given preoperative Alprazolam $+50 \mathrm{mg}$ of Tramadol and those who were not given Alprazolam + Tramadol preoperatively. We found that the combination of Alprazolam given in the preoperative period with $100 \mathrm{mg}$ of Tramadol was more effective on postoperative anxiety than the combination of Alprazolam with $50 \mathrm{mg}$ of Tramadol. Based on these findings, we think that administration of alprazolam in the preoperative period reduces the agitation experienced by the patients in the postoperative period.

We did not measure anxiety in the preoperative period in our study. We accepted that the patients had anxiety in the preoperative period and that the patients experienced agitation due to this anxiety. We decided to measure this existing agitation in the postoperative period. We used RASS to measure agitation in the postoperative period. RASS is a method frequently used in the evaluation of sedation level and agitation, especially in intensive care units.

Contrary to our hypothesis that agitation increased the perception of pain in patients, according to the results of our study, although the agitation scores were lower in Group 1, we did not find the VAS results as we expected. We cannot fully explain the reason for this.

\section{Study Limitations}

The limitations of our study were that the level of anxiety and agitation of the patients was not determined by the "psychiatry" clinic in the preoperative period, the same tests were not repeated postoperatively, patient satisfaction was not questioned in the postoperative period, and the evaluation of the VAS was a subjective evaluation.

\section{Conclusion}

We found that the RASS values of the patients in the group given preoperative $100 \mathrm{mg}$ Tramadol and Alprozam together were significantly lower than the other groups. In conclusion, we found that combining $100 \mathrm{mg}$ of Tramadol preoperatively with Alprazolam, an anxiolytic, effectively reduced anxiety in the postoperative period. Conducting more comprehensive, multicenter studies on this subject will enable a better understanding of the effects of preoperative anxiety on pain and anxiety in the postoperative period in patients undergoing breast cancer surgery.

\section{Ethics}

Ethics Committee Approval: The study was conducted with 120 ASA I-III class women in the 20-80 age group who underwent 
elective breast surgery between 2012 and 2014 in Cerrahpaşa Medical Faculty Monobloc Operating Room after obtaining the approval of the Ethics Committee of İstanbul UniversityCerrahpaşa Cerrahpaşa Faculty of Medicine. It was conducted clinically, randomized and prospectively.

Informed Consent: Before the patients participated in the study, the study was explained to the patients in detail and their written consent was obtained.

Peer-review: Externally peer reviewed.

\section{Authorship Contributions}

Concept: B.A., G.M.K., Design: B.A., G.M.K., Data Collection or Processing: B.A., G.M.K., Analysis or Interpretation: B.A., G.M.K., Literature Search: B.A., G.M.K., Writing: B.A., G.M.K.

Conflict of Interest: No conflict of interest was declared by the authors.

Financial Disclosure: The authors declared that this study received no financial support.

\section{References}

1. Zdenkowski N, Tesson S, Lombard J, Lovell M, Hayes S, Francis PA, Dhillon HM, Boyle FM. Supportive care of women with breast cancer: key concerns and practical solutions. Med J Aust 2016;205:471-5.

2. Villar RR, Fernández SP, Garea CC, Pillado MTS, Barreiro VB, Martín CG. Quality of life and anxiety in women with breast cancer before and after treatment. Rev Lat Am Enfermagem 2017;25:e2958.

3. Liesto S, Sipilä R, Aho T, Harno H, Hietanen M, Kalso E. Psychological resilience associates with pain experience in women treated for breast cancer. Scand J Pain 2020;20:545-53.

4. Kissin I. Preemptive analgesia. Anesthesiology 2000;93:1138-43.

5. Węgorowski P, Stanisławek A, Domżał-Drzewicka R, Sysiak J, Rząca $\mathrm{M}$, Milanowska J, et al. The effect of pre-emptive analgesia on the level of postoperative pain in women undergoing surgery for breast neoplasm. Contemp Oncol (Pozn) 2016;20:158-64.

6. Doleman B, Leonardi-Bee J, Heinink TP, Bhattacharjee D, Lund JN, Williams JP. Pre-emptive and preventive opioids for postoperative pain in adults undergoing all types of surgery. Cochrane Database Syst Rev 2018;12:CD012624.

7. Kelly DJ, Ahmad M, Brull SJ. Preemptive analgesia I: physiological pathways and pharmacological modalities. Can J Anaesth 2001;48:1000-10.

8. Bravo L, Mico JA, Berrocoso E. Discovery and development of tramadol for the treatment of pain. Expert Opin Drug Discov 2017;12:1281-91.

9. Yarramalle SP, Munta K, Rao SM, Venkategowda PM, Sunka S, Dudam SK. Comparision of Analgesic Efficacy of Tramadol Infusion Versus Tramadol Plus Ondansetron Infusion In Medical Intensive Care Unit. Indian J Crit Care Med 2018;22:353-6.

10. Tsaousi GG, Chatzistravou A, Papazisis G, Grosomanidis V, Kouvelas D, Pourzitaki C. Analgesic Efficacy and Safety of Local Infiltration of
Tramadol in Pediatric Tonsillectomy Pain: A Systematic Review and Meta-Analysis. Pain Pract 2020;20:550-63.

11. Joseph TT, Krishna HM, Kamath S. Premedication with gabapentin, alprazolam or a placebo for abdominal hysterectomy: Effect on preoperative anxiety, post-operative pain and morphine consumption. Indian J Anaesth 2014;58:693-9.

12. Avanaz A, Yaprak M, Doğru V, Mesci A, Akbaş M, Kısaoğlu C, et al. Effect of Alprazolam as a Preoperative Adjuvant Analgesic on Postoperative Pain in Laparoscopic Donor Nephrectomy Patients. Transplant Proc 2019;51:1044-8.

13. Yücel A. Postoperatif Analjezi. Istanbul. 2004:7-68,145-157.

14. Badner NH, Nielson WR, Munk S, Kwiatkowska C, Gelb AW. Preoperative anxiety: detection and contributing factors. Can J Anaesth 199;37:444-7.

15. Gönüllü M, Turan ED, Erdem LK. Anestezi uygulanacak hastalarda anksiyete düzeyinin araştırılması. Türk Anest ve Rean Cem 1986;14:110-3.

16. Chew ST, Tan T, Tan SS, Ip-Yam PC. A survey of patients' knowledge of anaesthesia and perioperative care. Singapore Med J 1998;39:399402.

17. Moerman N, Van Dam FSAM, Muller MJ. The Amsterdam preoperative anxiety and information scala. Anasth Analg 1996;82:445-51.

18. Vickers MD, O’Flaherty D, Szekely SM, Read M, Yoshizumi J. Tramadol: pain relief by an opioid without depression of respiration. Anaesthesia 1992;47:291-6.

19. Lichtor JL, Johanson CE, Mhoon D, Faure EA, Hassan SZ, Roizen MF. Preoperative anxiety: does anxiety level the afternoon before surgery predict anxiety level just before surgery? Anesthesiology 1987;67:595-9.

20. Baykara N. Santral sensitizasyon ve preemptif analjezi. Sendrom 2000:12;69-75.

21. Wang F, Shen X, Xu S, Liu Y. Preoperative tramadol combined with postoperative small-dose tramadol infusion after total abdominal hysterectomy: a double-blind, randomized, controlled trial. Pharmacol Rep 2009;61:1198-205.

22. Pozos-Guillen A, Martinez-Rider R, Aguirre-Banuelos P, Perez-Urizar J. Pre-emptive analgesic effect of tramadol after mandibular third molar extraction: a pilot study. J Oral Maxillofac Surg 2007;65:131520.

23. Olmez G, Kaya S, Aflay U, Sahin H. Comparison of lornoxicam versus tramadol analgesia for transrectal prostate biopsy: a randomized prospective study. Int Urol Nephrol 2008;40:341-4.

24. Møiniche S, Kehlet H, Dahl JB. A qualitative and quantitative systematic review of preemptive analgesia for postoperative pain relief: the role of timing of analgesia. Anesthesiology 2002;96:72541.

25. Bösenberg AT, Ratcliffe S. The respiratory effects of tramadol in children under halothane an anaesthesia. Anaesthesia 1998;53:960-4.

26. Pasnau RO, Fawzy FI, Skotzko CE et al. Surgeryandsurgicalsubspecialties, The American Psychiatric Press 
Textbook of Consultation-LiaisonPsychiatry. JR Rundell, MG Wise (Ed), Washington DC., AmericanPsychiatricPressInc

27. Surman OS Thesurgicalpatient, Massachusetts General HospitalHandbook of General HospitalPsychiatry. TP Hackett, NH Cassem (Ed), 2. Baský, Littleton, PSG Publishing,1987,s.69-83
28. De Witte JL, Alegret C, Sessler DI, Cammu G. Preoperative alprazolam reduces anxiety in ambulatory surgery patients: a comparison with oral midazolam. Anesth Analg 2002;95:1601-6. 